\title{
Torrefaction of olive mill waste
}

\author{
Verónica Benavente", Andrés Fullana \\ Chemical Engineering Department, University of Alicante, Ap. 99, E-03080 Alicante, Spain \\ *Corresponding author. E-mail: veronica.benavente@ua.es. Tlf.: +(34) 965903400 ext. 1116. \\ Fax: +(34) 965903826 .
}

\begin{abstract}
Two-phase olive mill waste (TPOMW) was converted via torrefaction into a carbon rich solid interesting as bioenergy feedstock. TPOMW was characterized and torrefied in an oven at temperatures ranging from 150 to $300^{\circ} \mathrm{C}$ for 2 hours. Mass and energy losses occurred during torrefaction were measured and the torrefied products were characterized including ultimate analysis, heating value measurements, accelerate solvent extraction (ASE) and FTIR in order to assess the effects of torrefaction on the physicochemical properties of TPOMW. Additionally, ash fouling evaluation was also performed through $\mathrm{XRF}$ analysis. The weight fraction of $\mathrm{C}$, defined in percentage as wt. $\%$, improved from 56 to $68 \mathrm{wt} . \%$ and the high heating value rose from 26.4 to 30.0 $\mathrm{MJ} \cdot \mathrm{kg}-1$ as torrefaction temperature increased, reaching typical values of subbituminous coal and finding the best results at $200{ }^{\circ} \mathrm{C}$ in terms of maximizing the heating value and minimizing the energy losses. Accordingly, from FTIR analysis it was observed that the degree of coalification increased during torrefaction of TPOMW. ASE results shown that the residual olive oil in TPOMW was removed during torrefaction, being completely eliminated at $300{ }^{\circ} \mathrm{C}$. The alkali index for TPOMW was
\end{abstract}


25 found to be $0.66 \mathrm{~kg}$ alkali $\bullet \mathrm{GJ}-1$, which implied a high fouling tendency that could be mitigated through co-firing. Finally, t-TPOMW briquettes with good mechanical strength and energy density of $26.7 \mathrm{GJ} \bullet \mathrm{m}-3$ were produced using a hydraulic piston press. Results demonstrated that torrefaction allows transforming TPOMW into a coallike material, which would imply a profitable way to manage these wastes.

Keywords: Torrefaction, biomass, upgrading, olive mill waste, densification, bioenergy.

\section{Introduction}

Motivated by the transition to a more sustainable society based on clean energy technologies, biomass emerges as one of the most important renewable energy sources, on the one hand, due to its environmental benefits, since bioenergy could imply a reduction in the carbon dioxide emissions and contributes to decrease the environmental economic development of rural areas and enhances energy access $[1,2]$. Over the past decade, the bioenergy utilization increased from $8 \%$ of the world total primary energy supply to $10 \%$ today and it is expected to rise further to between $25 \%$ and $33 \%$ by 2050 [1]. However, an important transition required to achieve this vision is to use biomass more efficiently by deploying more efficient conversion technologies and better integrating bioenergy production into biomass value chains in other industries.

There is a considerable bioenergy potential from several sources, since a wide range of feedstocks can be used for bioenergy generation, like energy crops, biomass residues and organic wastes. In the northern European countries, is common to refer to wood 
49 biomass (e.g. bark, wood chips and sawdust). Nevertheless, the Mediterranean area has great bioenergy potential from several agricultural residues, especially from the olive oil sector as they produce over $98 \%$ of the worldwide production [3].

The olive-oil extraction process generates large amounts of byproducts and wastes that require a specific management regarding minimization, valorization and mitigation of their environmental impact. The new technology for olive-oil extraction is a continuous centrifugate two-phase process that generates a liquid phase (olive oil) and an organic slurry called two-phase olive mill waste (TPOMW, or 'alperujo' in Spanish). In Spain (major olive oil producer country), alone this new system generates approximately 300000 tons per year of TPOMW [4], which is a high polluting by-product due to its content in organic matter. Indeed, the pollutant power of TPOMW is very high (BOD 89-100 $\mathrm{g} \cdot \mathrm{L}^{-1}$, COD 80-200 $\mathrm{g} \cdot \mathrm{L}^{-1}$, being BOD and COD the Biological Oxygen Demand and the Chemical Oxygen Demand, respectively) as the TPOMW organic fraction includes sugars, polyalcohols, pectins, lipids and notable amounts of aromatic compounds that are responsible for phytotoxic and antimicrobial effects $[5,6]$. Nowadays, there is not an efficient elimination system of TPOMW due to its low energy density and its high moisture content, which makes it costly to transport, in combination with other technological limitations as low combustion efficiency [7]. Thus, it is imperative to find a proper disposal or utilization of viable management strategies.

Torrefaction is a mild pyrolysis process that can help to overcome some of the above mentioned limitations by converting biomass into an upgraded solid material with 
increased energy density and decreased oxygen content, therefore more suitable for energy generation. This method comprises thermal treating of material at temperatures from 200 to $300^{\circ} \mathrm{C}$ so that neither great initial investment nor high operating costs are required [7-9].

The torrefaction products are volatile (carbon dioxide, carbon monoxide and possible traces of acetic acid, hydrogen and methane), condensable and non-condensable gases (water vapor, acetic acid, furfural, formic acid, methanol, lactic acid, phenol), and a carbon-enriched solid, which is the main torrefaction product, that retains between 75 and 95\% from the departure energy content, depending on the processing conditions (pressure, temperature, residence time) and the feedstock [9]. Wannapeera and Worasuwannarak [10] studied the torrefaction under pressure of leucaena and found that the mass and energy yield was higher when raising the torrefaction pressure. Other authors [7, 11-15] examined the influence of torrefaction temperature and residence time on the properties of torrefied materials obtained from different feedstocks and observed that, although both parameters affect the product distribution and the properties of the solid, the temperature had more effect on torrefaction than the residence time. Pimchuai et al. [7] study the torrefaction in nitrogen atmosphere of rice husks, sawdust, peanut husks, bagasse and water hyacinth at temperatures ranging from $250^{\circ} \mathrm{C}$ to $300^{\circ}$, and found that the combustion properties of the torrefied materials were improved for the higher torrefaction temperatures investigated. Chen et al. [12] investigate the torrefaction behavior of lauan blocks and recommended the operation at $250^{\circ} \mathrm{C}$ and $1 \mathrm{~h}$ in order to intensify the heating value as well as to avoid too much mass loss of the initial wood and its conversion into condensed liquid. On the other hand, 
97 Rousset et al. [16] evaluated the combined effect of the temperature and oxygen concentrations on the physical and chemical properties of eucalyptus grandis and from the results it was possible to confirm that the oxygen concentration become important on the properties and compositions of the solid from over $280^{\circ} \mathrm{C}$, being negligible at lower temperatures.

The torrefied material is comparable with a low rank coal and still retains some characteristic properties from the original biomass but present higher energy content and better stability against microbial degradation due to the improved hydrophobic properties. Besides, torrefied biomass is a fragile and low density porous product that has a higher dust formation capacity and lower mechanical strength than fresh biomass due to the loss of structural integrity from the breakdown of hemicellulose [9]. Consequently, these characteristics make it necessary to volumetrically densify the torrefied material in order to facilitate its handling and reducing transport and storage costs.

Among the variety of densification systems, pellet mill and briquette press are the most common technologies used for producing a uniform format feedstock product for bioenergy applications [17]. Studies of torrefied biomass densification have indicate that the pressure and the energy required during the briquetting process are reduced by a factor of two while the performance increases twice as compared to the densification process of fresh biomass [17]. Hence, torrefaction combined with briquetting or pelletizing could be an efficient option for treating agricultural wastes and produce bioenergy feedstock. 
Despite torrefaction of diverse biomass resources can be found in the literature [12-14,

18-21], there is still a gap of information in the implementation of this technique as an

efficient management treatment to minimize and valorize problematic organic wastes, such as the TPOMW. In this work, the torrefaction method has been applied to TPOMW in order to study the viability of the process to produce bioenergy feedstock from the olive oil extraction waste. Different experiments were carried out at laboratory scale in order to determinate the optimum temperature of the process. Then, the torrefied materials were fully characterized in order to evaluate its potential as a biofuel. Finally, briquetting tests were performed to test the applicability of this technique to the torrefied TPOMW (t-TPOMW).

\section{Materials and Methods}

\subsection{Materials}

Fresh TPOMW was supplied by Extremadura Agricultural and Food Technological Centre (CTAEX) during the olive campaign for 2012-2013. This material was sun dried on the field for two weeks. Then, the residual moisture content was obtained from the total mass loss after drying the fresh TPOMW in an over at $105^{\circ} \mathrm{C}$ for $24 \mathrm{~h}$, which was found to be $5.8 \mathrm{wt} . \%$. The dried TPOMW material was milled in a grinder to attain homogeneity, since the olive pits were easy to detect among the dried pulp, sieved to obtain a particle size less than $0.5 \mathrm{~mm}$ (particle size distribution between 0.1 and 0.5 $\mathrm{mm}$ ) and characterized including ultimate analysis, ash content, heating value tests and thermal analysis. Results are summarized in Table 1. 


\subsection{Torrefaction experiment procedure}

Several tests were proposed to investigate the effect of the temperature on the TPOMW torrefaction process. To accomplish this, TPOMW was torrefied under different temperature conditions in an oven model UFP500 from Memmert GmbH with an internal volume of $108 \mathrm{~L}$. Experiments were carried out at 150, 200, 250 and $300{ }^{\circ} \mathrm{C}$ for 2 hours and the mass loss was registered at the end. Temperatures $150{ }^{\circ} \mathrm{C}$ and $200{ }^{\circ} \mathrm{C}$ were included in the studied torrefaction temperature range in order to analyze if any change happened to the olive oil retained in the waste and if it could have any effect on the solid product since the smoke point of the olive oil is $160^{\circ} \mathrm{C}$. In each experiment, $100 \mathrm{~g}$ of TPOMW were extended on a flat rectangular metal pan forming a thin layer. When the oven reached the operating temperature, the metal pan was introduced in it. After the specified residence time period, the metal pan was removed from the oven and the solid product was weight and cooled until room temperature. Then, it was stored in plastic sealed buckets for the subsequent characterization.

The torrefied samples (t-TPOMW-150, t-TPOMW-200, t-TPOMW-250, t-TPOMW300) were characterized through elemental analysis CHNS and heating value tests in order to compare their properties with the ones of the raw material (TPOMW).

\subsection{Analytical methods}

\subsubsection{Ultimate analysis, ash fouling evaluation}


A CHNS analysis for dried TPOMW and for each t-TPOMW sample was carried out in an Elemental CHNS Microanalyzer Thermo Finningan Flash 1112 Series. The ash content of dried TPOMW was determined by thermal treating of TPOMW in a Muffle serie-74 model 12-R/300 from Heron at $550{ }^{\circ} \mathrm{C}$ during 8 hours under atmospheric condition. Oxygen content was calculated by subtraction of the ash and the CHNS content from the total. It should be noted that the ash content for t-TPOMW samples was recalculated from the content found for TPOMW by considering the mass loss occurred during torrefaction. In addition, X-ray fluorescence (XRF) analysis was used to determine the ash composition in order to assess the ash fusibility. A Philips Analytical MagiX-PRO X-ray Fluorescence Spectrometer (XRF) was used to determine the ash compositions in terms of weight fractions of the main oxide constituents.

\subsubsection{Heating value measurement}

Heating values of dried TPOMW and t-TPOMW were measured using an AC-350

Oxygen Bomb Calorimeter from Leco Corporation, which had an integral watermeasuring and combustion vessel-filling station. The equipment was calibrated using benzoic acid and the measurement was performed at least by duplicate for each sample. About $1 \mathrm{~g}$ of sample was loaded into the apparatus and combusted at $25^{\circ} \mathrm{C}$ under a pressure of $3 \mathrm{MPa}$ of pure oxygen.

\subsubsection{Thermogravimetric analysis (TGA)}

A Perkin Elmer Pyris TGA/STA 6000 Thermogravimetric Analyzer was used to check the thermal stability of dried TPOMW both in inert atmosphere. The sample mass was 
around $5 \mathrm{mg}$ and the heating program consisted on a 1 min hold at $35^{\circ} \mathrm{C}$ and ramp up to $600^{\circ} \mathrm{C}$ at $20^{\circ} \mathrm{C} \cdot \mathrm{min}^{-1}$ under nitrogen flow of $20 \mathrm{~mL} \cdot \mathrm{min}^{-1}$.

\subsubsection{Accelerate solvent extraction (ASE)}

All the samples were subjected to accelerated extraction with hexane in order to determine the residual content of olive oil. For this purpose, a Dionex ${ }^{\mathrm{TM}}$ ASETM $^{\mathrm{T}} 150$ Accelerated Solvent Extractor equipment was employed under the following conditions: $10 \mathrm{MPa}, 100{ }^{\circ} \mathrm{C}$, static time of 5 minutes, 3 static cycles, $70 \%$ flush and a purge time of $120 \mathrm{~s}$. After extraction, the content of the pre-weighed extraction vials were evaporated to dryness and the weight of the residue obtained was used to calculate the amount of olive oil in the original samples.

\subsubsection{FTIR spectroscopy}

FTIR analyses of TPOMW and t-TPOMW were performed with a BRUKER IFS 66/S instrument using pellets of potassium bromide that was previously oven-dried to reduce interferences from water. Additionally, an olive oil sample was also examined by depositing a small quantity between two well-polished $\mathrm{KBr}$ disks to create a thin film. Each spectrum was recorded in the wavenumber range from 4000 to $600 \mathrm{~cm}^{-1}$ with a resolution of $2 \mathrm{~cm}^{-1}$.

\subsection{Briquetting tests}

Finally, a hydraulic piston press fitted with an electrical oven was used to produce tTPOMW briquettes. Compression cell allows the production of a $5 \mathrm{~cm}$ diameter briquette. The procedure consisted of making two successive compressions and 
decompressions at $200^{\circ} \mathrm{C}$ under $17 \mathrm{MPa}$, and subsequently cooling to room temperature while maintaining the pressure, being the briquette finally demolded. Then, the briquettes were extracted in the ASE equipment under the same conditions than before (see point 2.3.4.) in order to determine the percentage of residual olive oil removed from the torrefied material during the briquetting tests.

\section{Results and Discussion}

\subsection{Torrefaction of TPOMW}

\subsubsection{Characteristics of TPOMW and t-TPOMW}

Figure 1 shows the appearance of the torrefied materials derived at the various temperatures. Visually, it was found that the appearance of the samples evolved from a brown lignocellulosic to black coal-like as the torrefaction process was more severe.

Table 1 shows the ultimate analysis, the residual olive oil content and the high heating value (HHV) for the raw and torrefied materials (TPOMW and t-TPOMW). It is noted that the weight fraction of carbon, defined in percentage as wt.\%, increases from 56 to $68 \mathrm{wt} . \%$ with the increase in the torrefaction temperature due to the elimination of oxygen and hydrogen [9]. The HHV is higher than $28 \mathrm{MJ} \cdot \mathrm{kg}^{-1}$ (dry basis) for tTPOMW-200, t-TPOMW-250 and t-TPOMW-300. Thus, the HHV of the torrefied products increases between 8.6 and $13.4 \%$ for the samples obtained at torrefaction temperatures equal to or above $200{ }^{\circ} \mathrm{C}$, being the $\mathrm{HHV}$ rise defined as $\mathrm{HHV}$ rise $=$ $\left(\left(\mathrm{HHV}_{\mathrm{T}}-\mathrm{HHV}_{0}\right) / \mathrm{HHV}_{0}\right) \cdot 100$, where the $\mathrm{HHT}_{\mathrm{T}}$ is the high heating value of the torrefied 
sample obtained at temperature $\mathrm{T}$ and $\mathrm{HHV}_{0}$ is the high heating value of raw TPOMW. Comparing this result with the literature, it is observed that the rise in the HHV contents are lower than those found for other torrefied agricultural residues, such as rice hulks, sawdust, peanut husks, bagasse and water hyacinth [7], whose HHV rises reach values over $20 \%$ at $300^{\circ} \mathrm{C}$. However, the HHV of TPOMW is higher than those for the aforementioned residues, and consequently, the torrefied TPOMW samples are more energetic than the torrefied products obtained from the feedstocks mentioned before, reaching typical values of subbituminous coal [22].

Figure 2.a presents the $\mathrm{CHO}$ diagram, which illustrates the effect of torrefaction temperature on the ultimate analysis of the torrefied material obtained. Weight fractions of $\mathrm{C}, \mathrm{H}$ and $\mathrm{O}$ are normalized as wt. $\% \mathrm{C}+\mathrm{wt} . \% \mathrm{H}+\mathrm{wt} . \% \mathrm{O}=100$ for each t-TPOMW sample. In addition, the $\mathrm{CHO}$ composition of carbon dioxide, carbon monoxide, water vapor and acetic acid is also included in Figure 2.a, as they are expected to be the main volatile and non-condensable products in torrefaction $[8,9,23]$. In that sense, the $\mathrm{CHO}$ composition of oleic acid is represented as well.

It is observed that the $\mathrm{C}, \mathrm{H}$ and $\mathrm{O}$ wt.\% depends on the thermal treating temperature. $\mathrm{C}$ wt.\% increases as the temperature does, while the $\mathrm{O}$ wt.\% decreases and $\mathrm{H}$ wt.\% remains almost constant until $250^{\circ} \mathrm{C}$, from which temperature it slightly decreases. Furthermore, a mass balance over the ternary diagram was done. It is observed that, as temperature increases, the t-TPOMW composition linearly moves in the opposite direction to the area over which the carbon dioxide, carbon monoxide, vapor water and acetic acid are situated. This observation suggests that, on the one hand, these 
components could have been released during the torrefaction process as constituents of the gas product flow, in agreement with the literature [9], and, on the other hand, that they were released in higher quantities as the temperature increased, as expected, due to a higher extent of the reactions involved during the torrefaction process. Accordingly, it could be said in rough outlines that at temperatures below $250{ }^{\circ} \mathrm{C}$ the major reaction pathways would have been decarboxylation reactions to form carbon monoxide, carbon dioxide and solid torrefied TPOMW while at higher temperatures dehydration and deacetylization reactions would also have become important. At $300^{\circ} \mathrm{C}$, t-TPOMW also moves in the opposite direction over which oleic acid (main component of olive oil) is placed, which suggests that the residual olive oil that still remained in the TPOMW was removed during torrefaction.

In Table 1 is shown the olive oil content determined through ASE analysis. It is seen that residual olive oil was removed during torrefaction, being completely eliminated at $300{ }^{\circ} \mathrm{C}$, as predicted from the results observed in elemental analysis. Therefore, from these results it could be concluded that torrefaction improves the properties of TPOMW as a bioenergy feedstock, not only because enhance the carbon content and its heating value but also because depending on torrefaction temperature, decreases or even entirely removes the residual olive oil content, thus preventing from possible odors.

It is known that olive oil is composed mainly of mixed triglyceride esters of oleic acid and palmitic acid and of other fatty acids, which decompose before vaporization. Font and Rey [24] carried out a kinetic study of olive oil pyrolysis by thermogravimetry and determined that the decomposition of the olive oil occurs in the temperature range of 
230- $480{ }^{\circ} \mathrm{C}$ under the scheme of two consecutive reactions. The first global reaction takes place between 280 and $450{ }^{\circ} \mathrm{C}$ and represents a process with decomposition reactions and vaporization of the products obtained, whereas the second global reaction takes place between 380 and $480{ }^{\circ} \mathrm{C}$ and involved complex decomposition reactions of the products obtained in reaction 1. Consequently, the residual olive oil was removed from the solid by means of decomposition reactions and volatilization of the products formed during torrefaction.

t-TPOMW samples are also situated on the van Krevelen diagram (Fig. 2.b), where the transition from the biomass composition to the corresponding coal is indicated. By this figure, it is intended to illustrate that torrefaction allows transforming the TPOMW into a material with characteristics similar to those of carbon, showing again the fall of the $\mathrm{H} / \mathrm{C}$ ratio against to that corresponding to oleic acid at temperatures higher than $200^{\circ} \mathrm{C}$.

\subsubsection{Termogravimetric análisis}

Figure 3 shows the TG and DTG curves obtained at $20^{\circ} \mathrm{C} \cdot \mathrm{min}^{-1}$ in nitrogen flow of 20 $\mathrm{mL} \cdot \mathrm{min}^{-1}$ for TPOMW. The DTG curves show three consecutive degradation steps. Furthermore, the pyrolysis reaction produces a carbonaceous residue that represents the 20 wt.\% of the raw material. This result is consistent with the values found in the literature for other kinds of biomass (e.g. $21 \mathrm{wt} . \%$ for spruce, $30 \mathrm{wt} . \%$ for straw and 25 $30 \mathrm{wt} . \%$ for eucalyptus and poplar) [25].

Like other biomass sources, the main organic constituents of TPOMW are hemicellulose (38 wt.\%), cellulose (21 wt.\%) and lignin (46 wt.\%) [5]. Hemicellulose 
pyrolysis mainly happens at $220-315^{\circ} \mathrm{C}$ and cellulose thermal degradation ranges from 315 to $400{ }^{\circ} \mathrm{C}$, presenting the maximum decomposition rate at $268^{\circ} \mathrm{C}$ and $355{ }^{\circ} \mathrm{C}$, respectively. On the other hand, lignin is thermally more stable and its degradation slowly happens under a wide temperature range from 100 to $900{ }^{\circ} \mathrm{C}$, being emphasized in the high temperature region $[23,26]$. Thus, the DTG peak at lower temperature is mainly attributed to hemicellulose devolatilization, the second peak mainly corresponds to cellulose decomposition and the last degradation step can involve the degradation of olive oil according to Font and Rey [24]. The degradation of lignin can be contained in the three decomposition steps. Torrefaction was carried out in the range of temperatures from 150 to $300{ }^{\circ} \mathrm{C}$, wherein only one degradation step occurs, representing a total mass loss of $20 \mathrm{wt} . \%$. Accordingly to these results, it is expected that thermal degradation of hemicellulose mainly takes place during torrefaction procedure at tested temperatures, while small degree of cellulose and lignin degradation as well as olive oil decomposition might occurs, which is in agreement with the literature [9, 24, 27].

\subsubsection{FTIR analysis}

The changes in the chemical structure of TPOMW during torrefaction were analyzed using FTIR spectroscopy. Figure 4 show the spectra of olive oil, TPOMW and tTPOMW samples. Accordingly, Table 2 reports the assignment of the foremost infrared absorption bands $[8,28]$.

The olive oil characteristic bands that appear from 1162 to $1243 \mathrm{~cm}^{-1}$ and at $1739 \mathrm{~cm}^{-1}$ belong, respectively, to aliphatic ether and alcohol groups and to ester groups, which are also forming part of the chemical structure of hemicellulose and cellulose from 
TPOMW. As torrefaction temperature rises, it is seen that the intensity of the peaks decreases, which might indicate that the following processes occurs during torrefaction: the degradation of carbohydrates through dehydratation and decarboxylation reactions (including the olive oil elimination, as concluded from accelerate solvent extraction results); and the removal of ester group due to deacetylation reactions in hemicellulose.

Likewise, the peaks located at $723 \mathrm{~cm}^{-1}$ and in the range from 1377 to $1461 \mathrm{~cm}^{-1}$ are attributed to alkyl C-H groups bending. Hence, the reduction of the intensity of these peaks again indicates a significant thermal degradation of lipids and carbohydrates and the loss of aliphatic chains, which might be related to depolymerization of hemicellulose, since this is the most vulnerable fraction during torrefaction, as seen in the thermogravimetric analysis. Related to this change, it is observed an increase of the peaks ascribed to aromatic skeletal vibrations, which are placed in the range from 1508 to $1650 \mathrm{~cm}^{-1}$. Thus, in agreement with the literature [8], this increase supports the assumption that thermal treatment induces the cleavage of ether bond in lignin and the condensation of lignin by linking carbons directly. On the other hand, the loss of carbohydrates also contributes to augment the relative amount of lignin, and therefore, the intensity of the absorption bands corresponding to $\mathrm{C}=\mathrm{O}$ as the torrefaction temperature increases.

Thereby, the increase intensity of FTIR signal from aromatic and condensed structure in detriment of aliphatic ones is indicating that the degree of coalification increases during TPOMW torrefaction, being in good agreement with the results presented before. 


\subsubsection{Ash fouling evaluation}

One of the major problems associated with biomass combustion is the deposit formation in the convective passes of boilers. These deposits, referred to as slagging and fouling deposits, can drastically reduce heat transfer, cause erosion by channelizing gas flow, and contribute to the corrosion of exposed metal surfaces [29].

The propensity of fuels for producing slagging and fouling deposits depends on its ash composition. Elements including $\mathrm{Si}, \mathrm{K}, \mathrm{Na}, \mathrm{S}, \mathrm{Cl}, \mathrm{P}, \mathrm{Ca}, \mathrm{Mg}$ and $\mathrm{Fe}$ are involved in reactions leading to ash fouling and slagging. As expected from the literature [5, 29-31], TPOMW-ashes were specially rich in potassium and silicon, which portend potentially severe ash deposition problems at high or moderate combustion temperatures due to two primary sources: the reaction of alkali with silica to form alkali silicates that melt or soften at low temperatures; and the reaction of alkali with sulfur to form alkali sulfates on combustor heat transfer surfaces.

Although all biomass fuels exhibit fouling behavior, there exist different rates depending on the ash content and composition. Results of the X-ray fluorescence (XRF) analysis are shown in Table 3.

The alkali index is one of the most significant threshold indicator for fouling and slagging and expresses the quantity of alkali oxide in the fuel per unit of fuel energy $(\mathrm{kg}$ alkali. $\left.\mathrm{GJ}^{-1}\right)$. This parameter is calculated by eq. 1 , in which HHV is the high heating value of the fuel, $\mathrm{Y}_{\mathrm{f}}^{\mathrm{a}}$ is the weight fraction of ash in the fuel and $\mathrm{Y}_{\mathrm{K} 2 \mathrm{O}}{ }^{\mathrm{a}}$ and $\mathrm{Y}_{\mathrm{Na} 2 \mathrm{O}}{ }^{\mathrm{a}}$ are the weight fractions of $\mathrm{K}_{2} \mathrm{O}$ and $\mathrm{Na}_{2} \mathrm{O}$ in the ash [29]. 


$$
\text { Alkali index }=\frac{\mathrm{Y}_{\mathrm{f}}^{\mathrm{a}}\left(\mathrm{Y}_{\mathrm{K}_{2} \mathrm{O}}^{\mathrm{a}}+\mathrm{Y}_{\mathrm{Na}_{2} \mathrm{O}}^{\mathrm{a}}\right)}{\mathrm{HHV}} \quad \text { [eq. 1] }
$$

385 Above $0.17 \mathrm{~kg}$ alkali $\mathrm{GJ}^{-1}$ fouling is probable and above $0.34 \mathrm{~kg} \mathrm{GJ}^{-1}$ fouling is theoretically certain to occur [29]. According to eq.1, the alkali index for TPOMW is found to be $0.66 \mathrm{~kg}$ alkali. $\mathrm{GJ}^{-1}$, which is typical from herbaceous and fruit biomass (e.g. $0.50 \mathrm{~kg}$ alkali $\cdot \mathrm{GJ}^{-1}$ for rice hulls and $0.85 \mathrm{~kg}$ alkali $\cdot \mathrm{GJ}^{-1}$ for almond shells) and implies that fouling per alkali metals during combustion of TPOMW would occur. Comparing to other fuels, woody biomass has lower alkali index $\left(0.14 \mathrm{~kg}\right.$ alkali $\cdot \mathrm{GJ}^{-1}$ for willow wood and hybrid poplar) while coal only presents $0.03 \mathrm{~kg}$ alkali $\cdot \mathrm{GJ}^{-1}$ [29]. Accordingly, fouling tendency of TPOMW could be mitigated through co-firing of TPOMW with appropriate amounts of coal or woody biomass, which present less slagging and fouling problems $[29,30]$. A broad combination of fuels have been co-fired in pulverized coal combustion boilers with different proportions of biomass-coal (from $1 \%$ to $20 \%$ ) and experiences has demonstrated that co-firing resulted in less corrosion and ash deposition problems [31]. Then, though co-firing herbaceous biomass tends to be more difficult and costly than others because of its higher inorganic matter content, it would be possible to co-fire such fuels if there were a regulatory incentive to do so [31].

\subsubsection{Mass and Energy yield}

Energy densification via torrefaction allows increasing the heating value through the volatilization of the non-energy compounds while the material energy content is kept as possible [9]. The energy recover (ER) is defined as the energy retained by the solid product, which can be determined by eq.2, in which $\mathrm{Y}_{\text {solid }}$ represents the solid yield 
406 (expressed as \%), which is defined as $\mathrm{Y}_{\text {solid }}=\left(\mathrm{m}_{\mathrm{T}} / \mathrm{m}_{0}\right) \cdot 100$, where $\mathrm{m}_{\mathrm{T}}$ is the mass of torrefied material produced at temperature $\mathrm{T}$ and $\mathrm{m}_{0}$ the initial mass of dry TPOMW.

$$
\mathrm{ER}=\mathrm{Y}_{\text {solid }}\left(\frac{\mathrm{HHV}_{\mathrm{T}}}{\mathrm{HHV}_{0}}\right) \cdot 100 \quad[\text { eq. 2] }
$$

Figure 5 shows the $\mathrm{Y}_{\text {solid }}(\%)$ and the ER (\%) of t-TPOMW found for each experimental temperature. It can be observed that the ER and the solid yield continually decreases with the increase in the torrefaction temperature, due to the decomposition of some reactive components of the hemicelluloses and the consequent gas products (e.g. carbon monoxide, carbon dioxide, vapor water an acetic acid) volatilization. Solid yield and energy recovery are in the range of approximately 35-98\% of the initial weight and 40biomass is different during torrefaction. 


$$
\mathrm{TEI}=\left(\frac{\mathrm{HHV} \text { rise }}{\left(100-\mathrm{ER}_{\mathrm{T}}(\%)\right)}\right) \cdot 10
$$
energy losses. In Eq. 3, $\mathrm{ER}_{\mathrm{T}}$ are referred to temperature $\mathrm{T}$. [eq. 3]

value of TEI indicates greater HHV rise or energy densification improvement and lower

Figure 6 shows the representation of calculated TEI as a function of temperature for TPOMW. As seen in Figure 6, this parameter was also calculated for other agricultural wastes according to the results found by Pimchuai et al. [7]. The curve corresponding to TPOMW present a maximum that indicates the temperature conditions under torrefaction must be carried out accordingly with the criteria assumed, which is found to be $200{ }^{\circ} \mathrm{C}$. This result is consistent with those observed for the other agricultural wastes, since their calculated TEI decrease with increasing torrefaction temperature, which indicates that for this type of materials torrefaction is more energy beneficial at low temperatures due to the energy losses become more important than the HHV rise achieved with increasing temperature. Furthermore, TEI values calculated for rice husks and peanut husks are higher than those obtained for TPOMW as a consequence of the higher HHV rise values and the similar energy losses found for them under the same operation conditions. On the other hand, the opposite behavior is observed for woody biomass, like sawdust: the higher the torrefaction temperature, the higher the TEI, which could be associated to the greater energy recoveries mentioned before as well as the higher HHV rise compared to torrefied agricultural wastes. Therefore, torrefaction of woody biomass could be more energy favorable at $300{ }^{\circ} \mathrm{C}$. 
451 At this point, it is worth mentioning that if the olive oil that still remains in the torrefied

TPOMW when torrefaction is carried out at $200^{\circ} \mathrm{C}$ might lead to likely problems of odors in future possible combustion applications, such in domestic stoves, from an environmental point of view, the torrefaction temperature would be higher than $250{ }^{\circ} \mathrm{C}$, in order to remove the residual olive oil from the bioenergy feedstocks, even though the energy recovery drops to the $40 \%$. Consequently, if necessary, torrefaction temperature should be based on a compromise solution between the energy and the environmental criteria.

\subsection{Densification of $t$-TPOMW}

t-TPOMW samples were fragile materials that present higher dust formation capacity than TPOMW, the more the higher was the torrefaction temperature. Furthermore, the energy density $\left(\mathrm{MJ} \cdot \mathrm{m}^{-3}\right)$ decreases as a result of the porosity generated by removing volatile compounds during torrefactrion. Therefore, it is necessary to volumetrically densify the t-TPOMW.

Some briquetting tests were carried out using t-TPOMW-200, t-TPOMW-250 and tTPOMW-300 in order to analyze the viability of the densification process. It was found that for all the three analyzed materials it is possible to produce briquettes having a bulk density of $1 \mathrm{~kg} \cdot \mathrm{cm}^{-3}$ and considerable mechanical strength at temperature of $200{ }^{\circ} \mathrm{C}$ and compression pressure of $17 \mathrm{MPa}$ due to during compression at high temperatures, the protein and starch plasticizes and the lignin softens above $140{ }^{\circ} \mathrm{C}$ [17], which improves the particles binding and, consequently, assists in increasing the briquettes strength. In addition, around a 4\% of the residual olive oil contained in t-TPOMW-200 and t- 
TPOMW-250 was also removed during stress application, with the over mentioned benefits in future purposes.

Table 4 shows the evolution of the energy density $\left(\mathrm{MJ} \cdot \mathrm{m}^{-3}\right)$ when applying the torrefaction process to TPOMW at $200^{\circ} \mathrm{C}, 250^{\circ} \mathrm{C}$ and $300^{\circ} \mathrm{C}$ and the briquetting method to torrefied TPOMW at $200{ }^{\circ} \mathrm{C}$ and $17 \mathrm{MPa}$. It is seen that the technology of torrefaction combined with densification is able to increase the energy density of TPOMW by approximately $232 \%, 237 \%$ and $242 \%$ for t-TPOMW-200, t-TPOMW-250 and t-TPOMW-300 briquettes, respectively, so that, briquetting is a feasible way to densify t-TPOMW feedstock. Additionally, Table 4 also shows the energy density of woody biomass, lignite and anthracite for comparison [32]. It is seen that energy density of densified torrefied materials are intermediate to low rank and high rank coals.

Al-Widyan et al. [33] evaluated the physical quality of olive cake briquettes made by compressing in a hydraulic press under different levels of stress, moisture content and dwell time. These authors indicated that for samples with low moisture content the most significant parameter on briquette quality was the level of stress and found that a stress level closed to $34 \mathrm{MPa}$ produced the best results, which may be considered as optimal stress. By comparing this pressure with that used for t-TPOMW briquetting, it can be seen that the stress level required to densify olive cake duplicates the stress level used to densify t-TPOMW. Hence, although more research is needed in order to optimize both the densification system and the variables that controlled the process, torrefaction is also beneficial to reduce the specific energy consumption during densification. 


\section{Conclusion}

Results have demonstrated that a profitable bioenergy feedstock can be produced via torrefaction of TPOMW, which implies a feasible elimination of this agricultural waste. An increase of torrefaction temperature results in a linear decrease of oxygen content and higher $\mathrm{HHV}$, finding that, from an energy point of view, the temperature for TPOMW torrefaction lies nearby to $200{ }^{\circ} \mathrm{C}$. However, the TPOMW torrefied at this temperature still contain a $24 \mathrm{wt} . \%$ of olive oil. Then, in those energy applications where odors posed problems, torrefaction temperature should be based on a compromise solution between the energy and the environmental criteria. Besides, enhanced bulk density TPOMW briquettes with excellent mechanical strength can be produced using a hydraulic piston press at mild conditions. Summarizing, torrefaction combined with briquetting emerged as a promising option for treating two-phase olive mill waste and produce bioenergy feedstock.

\section{Acknowledgements}

This research was supported by the Spanish Ministry of Economy and Competitiveness (MINECO) and the European Regional Development Fund (FEDER) (IPT-2012-0565310000).

\section{References}

[1] International Energy Agency. Word Energy Outlook 2011. Available at <http://www.iea.org/publications/freepublications/publication/name,37085,en.html>; November 2013. 
[2] Schmidhube J. Impact of an increased biomass use on agricultural markets, prices and food security: A longer-term perspective. Available at <http://www.globalbioenergy.org/uploads/media/0704_Schmidhuber__Impact_of_an_increased_biomass_use_on_agricultural_markets_prices_and_food_se curity.pdf>; November 2013.

[3] International Olive Council. The world market in figures. Olivae 2012; 117: 28-34.

[4] Olive Oil Agency of Spanish Ministry of Agriculture, Fishing and Food. Report on the olive oil and table olives (Campain 2012-2013) 2013. Available at <http://www.faeca.es/files/Documentacion/Aceite\%20y\%20aceituna/Informe_AAO_ju n_2013.pdf>; November 2013.

[5] Alburquerque JA, Gonzálvez J, García D, Cegarra J. Agrochemical characterisation of "alperujo", a solid by-product of the two-phase centrifugation method for olive oil extraction. Bioresour Technol 2004; 91: 195-200.

[6] Roig A, Cayuela ML, Sánchez-Monedero MA. An overview on olive mill wastes and their valorisation methods. Waste Manage 2006; 26: 960-9.

[7] Pimchuai A, Dutta A, Basu P. Torrefaction of agriculture residue to enhance combustible properties. Energy Fuels 2010; 24: 4638-45. 
546 [8] Park J, Meng J, Lim KH, Rojas OJ, Park S. Transformation of lignocellulosic

547 biomass during torrefaction. J Anal Appl Pyrolysis 2013; 100: 199-206.

548

549 [9] Ciolkosz D, Wallace R. A review of torrefaction for bioenergy feedstock production.

$550 \quad$ Biofuel Bioprod Biorefining 2011; 5: 317-29.

551

552

[10] Wannapeera J, Worasuwannarak N. Upgrading of woody biomass by torrefaction under pressure. J Anal Appl Pyrolysis 2012; 96: 173-80.

554

[11] Duncan A, Pollard A, Fellouah H. Torrefied, spherical biomass pellets through the 556 use of experimental design. Appl Energy 2013; 101: 237-43.

557

[12] Chen W, Hsu H, Lu K, Lee W, Lin T. Thermal pretreatment of wood (Lauan)

block by torrefaction and its influence on the properties of the biomass. Energy 2011;

560 36: $3012-21$.

561

562

[13] Prins MJ, Ptasinski KJ, Janssen FJJG. Torrefaction of wood: part 1. Weight loss kinetics. J Anal Appl Pyrolysis 2006; 77(1):28-34.

[14] Prins MJ, Ptasinski KJ, Janssen FJJG. Torrefaction of wood: part 2. Weight loss 566 kinetics. J Anal Appl Pyrolysis 2006; 77(1):35-40. 
89

[15] Bergman PCA, Boersma AR, Zwart RWR, Kiel JHA. Torrefaction for biomass cofiring in existing coal-fired power stations "biocoal". Report ECN-C.05-013. Petten, The Netherlands: ECN; 2005.

[16] Rousset P, Macedo L, Commandré JM, Moreira A. Biomass torrefaction under different oxygen concentrations and its effect on the solid by-product. J Appl Anal Pyrolysis 2012; 96: 86-91.

[17] Tumuluru JS, Wright CT, Hess JR, Kenney KL. A review of biomass densification systems to develop uniform feedstock commodities for bioenergy application. Biofuel Bioprod Biorefining 2011; 5: 683-707.

[18] Uemura Y, Omar WN, Tsutsui T, Yusup SB. Torrefaction of oil palm wastes. Fuel 2001;90(8):2585-91.

[19] Arcate JR. Torrefied wood, an enhanced wood fuel. Bioenergy; 2002. Boise;Idaho; September 22-26;2002.

[20] Felfi FF, Luengo CA, Suarez JA, Beaton PA. Wood briquette torrefaction. Energy Sustain Develop 2005;9(3):19-22.

[21] Indian Institute of Science. Project completion on torrefaction of bamboo,http://cgpl.iisc.ernet.in; 2006. 
[22] NETL-National Energy Technology Laboratory. Cost and performance baseline for

fossil energy plants. Volume 3b: Low rank coal to electricity. Combustion cases. 2011;

594

DOE/NETL - 2011/1463.

595

596

597

598

599

600

601

602

603

604

605

606

607

608

609

610

611

612

613

614

615

[23] Özveren U, Özdogan ZS. Investigation of the slow pyrolysis kinetics of olive oil pomace using thermo-gravimetric analysis coupled with mass spectrometry. Biomass Bioenergy 2013, http://dx.doi.org/10.1016/j.biombioe.2013.08.011.

[24] Font R, Rey MD. Kinetics of olive oil pyrolysis. J Anal Appl Pyrolysis 2013; $103: 181-88$

[25] Van de Velden M, Baeyens J, Brems A, Janssens B, Dewil R. Fundamentals, kinetics and endothermicity of the biomass pyrolysis reaction. Renew Energy 2010; 35: $232-42$.

[26] Yang H, Yan R, Chen H, Lee DH, Zheng C. Characteristics of hemicellulose, cellulose and lignin pyrolysis. Fuel 2007; 86: 1781-8.

[27] Chen W-, Kuo P-. Isothermal torrefaction kinetics of hemicellulose, cellulose, lignin and xylan using thermogravimetric analysis. Energy 2011; 36: 6451-60.

[28] Droussi Z, D'orazio V, Provenzano MR, Hafidi M, Ouatmane A. Study of the biodegradation and transformation of olive-mill residues during composting using FTIR spectroscopy and differential scanning calorimetry. J Hazard Mater 2009; 164: 1281-5. 
617 [29] Jenkins BM, Baxter LL, Miles Jr. TR, Miles TR. Combustion properties of 618 biomass. Fuel Proces Technol 1998; 54: 17-46.

619

620 [30] Kalembkiewicz J, Chmielarz U. Ashes from co-combustion of coal and biomass:

621

New industrial wastes. Resour Conserv Recycl 2012; 69: 109-21.

622

[31] Al-Mansour F, Zuwala J. An evaluation of biomass co-firing in Europe. Biomass

Bioenergy 2010; 34: 620-9.

625

[32] Arias B, Pedida C, Fermoso J, Plaza MG, Rubiera F, Pis JJ. Influence of

torrefaction on the grindability and reactivity of woody biomass. Fuel Process. Technol. 2008; 89: 169-175.

629

[33] Canalís P, Royo J, Sebastián F, Pascual J, Tapia R. La co-combustión: una alternativa para la utilización de la biomasa residual. InfoPower 2003; 58: 11-4.

632

633 and stability of olive cake briquettes. Can Biosyst Eng 2002; 44: 3.41,3.46. 
641

Tables

642

643 Table 1. Ultimate analysis (\% dry basis), ash content (wt.\%), olive oil content (wt.\%)

644 and high heating values (HHV, MJ $\mathrm{kg}^{-1}$ ) of TPOMW and t-TPOMW samples and HHV

645 rise (\%) of t-TPOMW samples.

646

\begin{tabular}{|c|c|c|c|c|c|}
\hline Values (\% dry basis) & TPOMW & $\mathrm{t}-\mathrm{TPOMW}-150^{\circ} \mathrm{C}$ & t-TPOMW- $200^{\circ} \mathrm{C}$ & t-TPOMW- $250^{\circ} \mathrm{C}$ & t-TPOMW- $300^{\circ} \mathrm{C}$ \\
\hline \multicolumn{6}{|l|}{ Ultimate Analysis } \\
\hline $\mathrm{C}$ & 56.1 & 59.9 & 66.3 & 67.2 & 67.7 \\
\hline $\mathrm{H}$ & 7.4 & 8.0 & 8.9 & 8.0 & 4.1 \\
\hline $\mathrm{N}$ & 0.8 & 1.1 & 1.7 & 1.6 & 1.6 \\
\hline $\mathrm{O}$ & 29.9 & 25.0 & 16.2 & 14.0 & 10.1 \\
\hline S & $<0.1$ & $<0.1$ & $<0.1$ & $<0.1$ & $<0.1$ \\
\hline Ash content (wt.\% d.b.) & 5.5 & 5.6 & 6.5 & 8.7 & 15.7 \\
\hline $\begin{array}{l}\text { Olive oil content } \\
\text { (wt.\%d.b.) }\end{array}$ & 26.0 & 25.0 & 24.1 & 19.9 & 0.1 \\
\hline $\mathrm{HHV}\left(\mathrm{MJ} \cdot \mathrm{kg}^{-1}\right)$ & 26.4 & 26.5 & 28.7 & 29.4 & 30.0 \\
\hline HHV rise (\%) & - & 0.4 & 8.6 & 11.0 & 13.4 \\
\hline
\end{tabular}

647

648

649

650

651

652

653

654

655 
657 Table 2. Main functional groups of TPOMW and t-TPOMW on FTIR spectra.

\begin{tabular}{|c|c|c|c|}
\hline $\begin{array}{c}\text { Wave number } \\
\left(\mathrm{cm}^{-1}\right)\end{array}$ & Range $\left(\mathrm{cm}^{-1}\right)$ & Functional groups & Mode of vibration \\
\hline 673 & 640-701 & $\mathrm{O}-\mathrm{H}$ & bending (out of plane) \\
\hline 723 & - & $\begin{array}{c}\mathrm{C}-\mathrm{C} \\
-\left(\mathrm{CH}_{2}\right)_{\mathrm{n}^{-}} \\
-\mathrm{HC}=\mathrm{CH}-(\mathrm{cis}) \\
\end{array}$ & $\begin{array}{l}\text { bending (out of plane) } \\
\text { rocking } \\
\text { bending (out of plane) }\end{array}$ \\
\hline 1018 & $1006-1043$ & $-\mathrm{C}-\mathrm{O}$ & stretching \\
\hline 1162 & $1147-1211$ & $-\mathrm{C}-\mathrm{O}$ & stretching \\
\hline 1243 & $1211-1290$ & $-\mathrm{C}-\mathrm{O}$ & stretching \\
\hline 1377 & $1371-1382$ & $-\mathrm{C}-\mathrm{H}\left(\mathrm{CH}_{3}\right)$ & bending symmetric \\
\hline 1446 & $1446-1486$ & $-\mathrm{C}-\mathrm{H}\left(\mathrm{CH}_{3}\right)$ & bending assymmetric \\
\hline 1461 & $1446-1486$ & $-\mathrm{C}-\mathrm{H}\left(\mathrm{CH}_{2}\right)$ & bending scissoring \\
\hline 1508 & - & $\mathrm{C}=\mathrm{C}($ aromatic $)$ & stretching \\
\hline 1650 & $1640-1651$ & $\begin{array}{c}\mathrm{C}=\mathrm{C} \text { (aromatic) } \\
\mathrm{C}=\mathrm{O} \\
\text { (amine groups, amine II band) }\end{array}$ & $\begin{array}{l}\text { skeletel vibrations } \\
\text { stretching }\end{array}$ \\
\hline 1739 & $1677-1795$ & $-\mathrm{C}=\mathrm{O}$ (ester) & stretching \\
\hline
\end{tabular}

659

660

Table 3. XRF analysis of TPOMW-ashes (expressed as percentage of oxides by weight).

663

\begin{tabular}{lllllllllll}
\hline Oxide constituent & $\mathrm{K}_{2} \mathrm{O}$ & $\mathrm{SiO}_{2}$ & $\mathrm{MgO}$ & $\mathrm{P}_{2} \mathrm{O}_{5}$ & $\mathrm{CaO}$ & $\mathrm{Al}_{2} \mathrm{O}_{3}$ & $\mathrm{Fe}_{2} \mathrm{O}_{3}$ & $\mathrm{SO}_{3}$ & $\mathrm{TiO}_{2}$
\end{tabular}

\begin{tabular}{llllllllll}
\hline Ash basis (\%) & 31.9 & 27.8 & 18.4 & 6.8 & 5.5 & 5.1 & 1.6 & 1.1 & 0.2
\end{tabular}

664 
669

\begin{tabular}{|c|c|}
\hline Energy feedstock & Energy Density $\left(\mathbf{M J} \cdot \mathbf{m}^{-3}\right)$ \\
\hline TPOMW & 12397 \\
\hline t-TPOMW-200 & 11343 \\
\hline t-TPOMW-300 & 10385 \\
\hline t-TPOMW-200 briquette & 9366 \\
\hline t-TPOMW-250 briquette & 28712 \\
\hline t-TPOMW-300 briquette & 29410 \\
\hline For comparing* & 29994 \\
\hline Forest biomass & 12040 \\
\hline Low rank coal & 16300 \\
\hline High rank coal & 39000 \\
\hline
\end{tabular}

*Data from Canalí et al., 2003. 


\section{$672 \quad$ Figures}

673

674

675

676

677

678

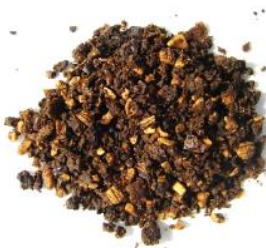

TPOMW

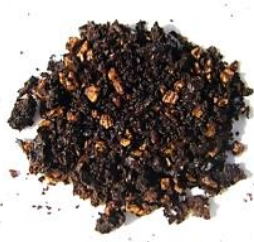

tTPOMW-150C

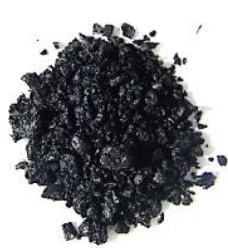

tTPOMW-200C

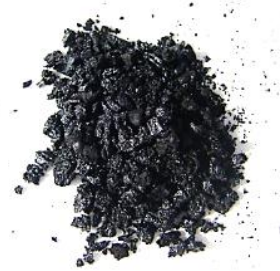

tTPOMW-250C

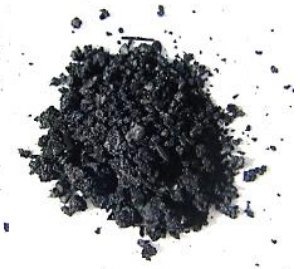

tTPOMW-300C

679 
Figure 2. A) Effect of torrefaction temperature illustrated in a CHO diagram.

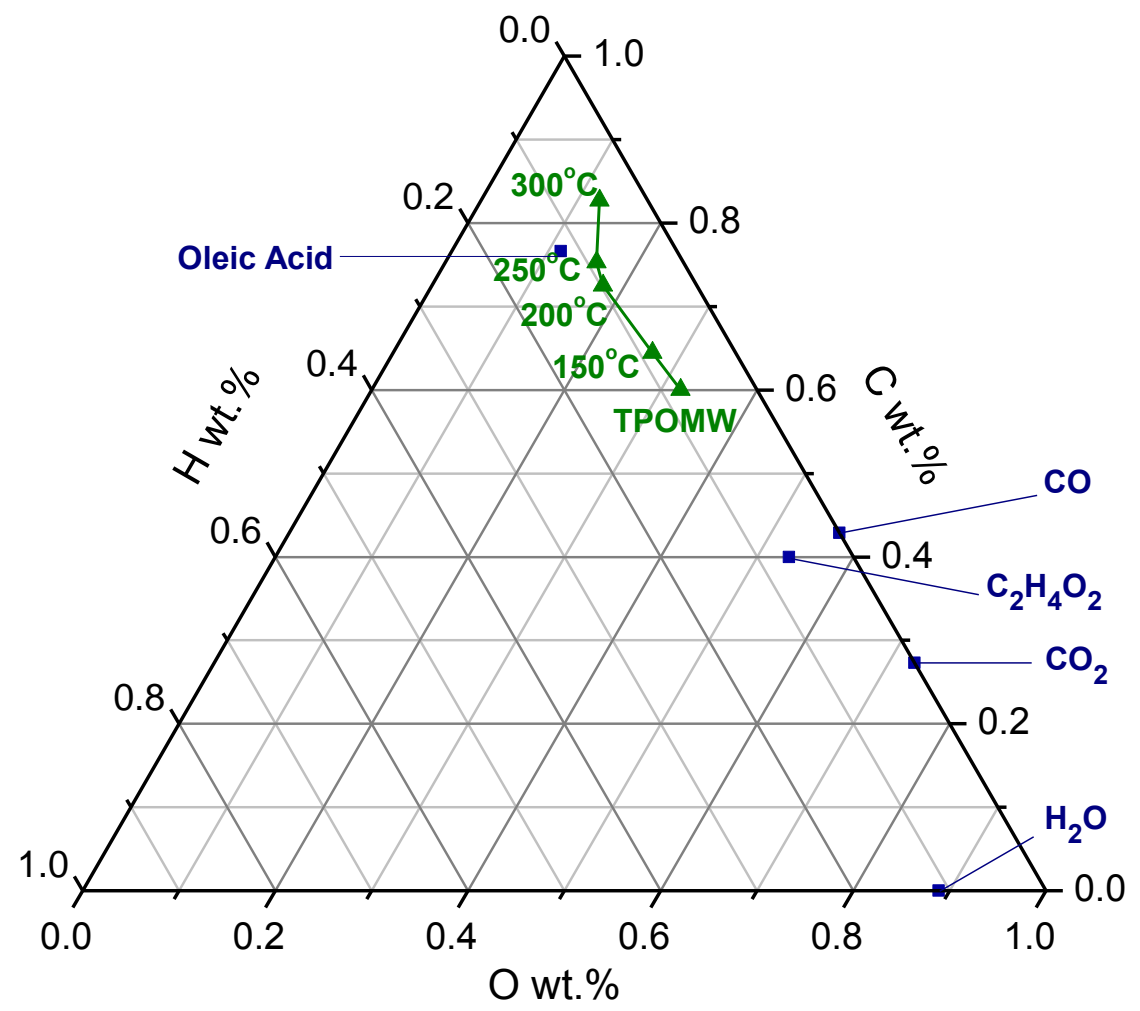

682 Figure 2. B) Compositional differences among TPOMW and t-TPOMW in van 683 Krevelen diagram.

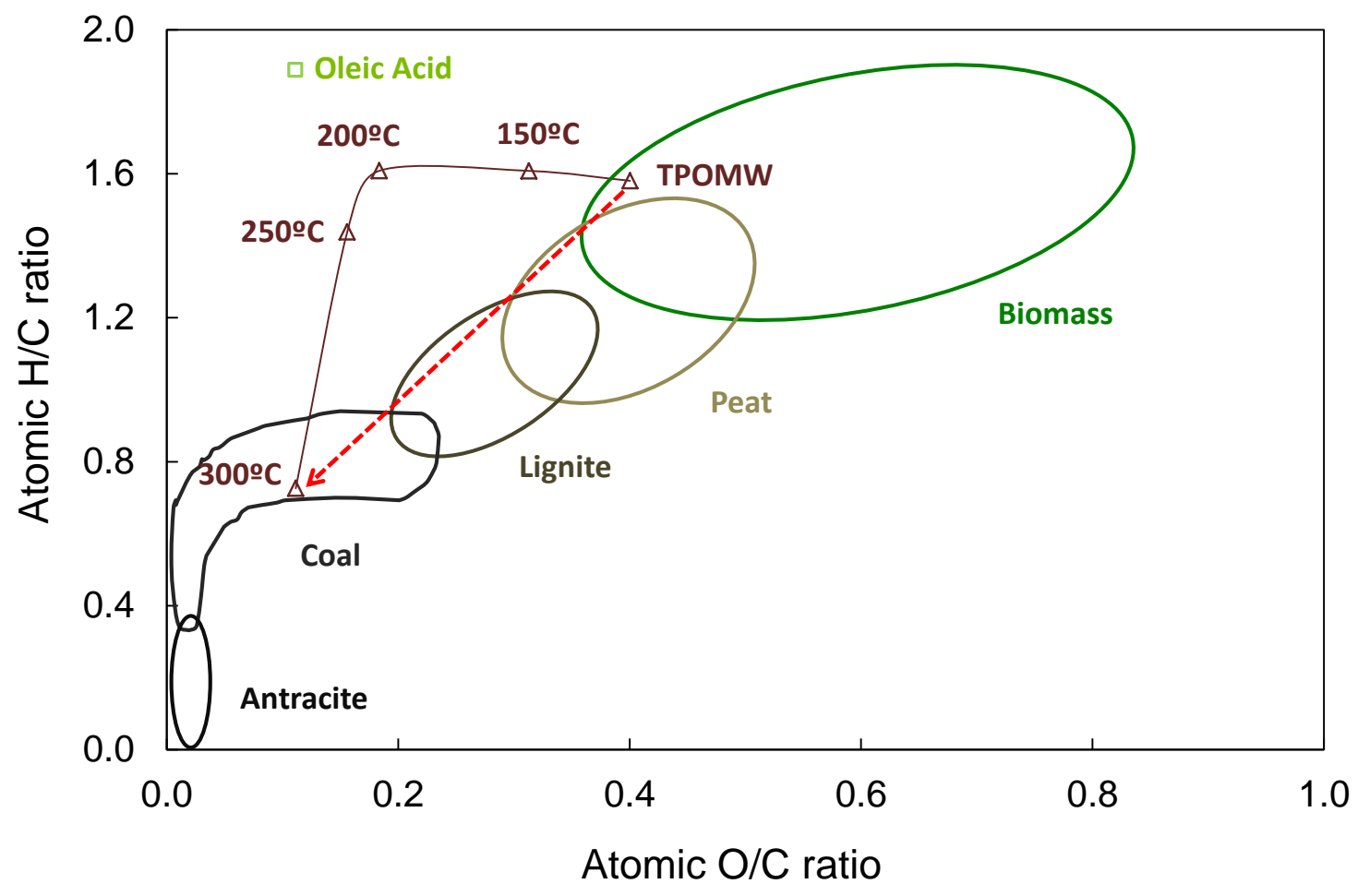


687

Figure 3. TG and DTG cuves for TPOMW at $20^{\circ} \mathrm{C} \cdot \mathrm{min}^{-1}$ under nitrogen atmosphere.

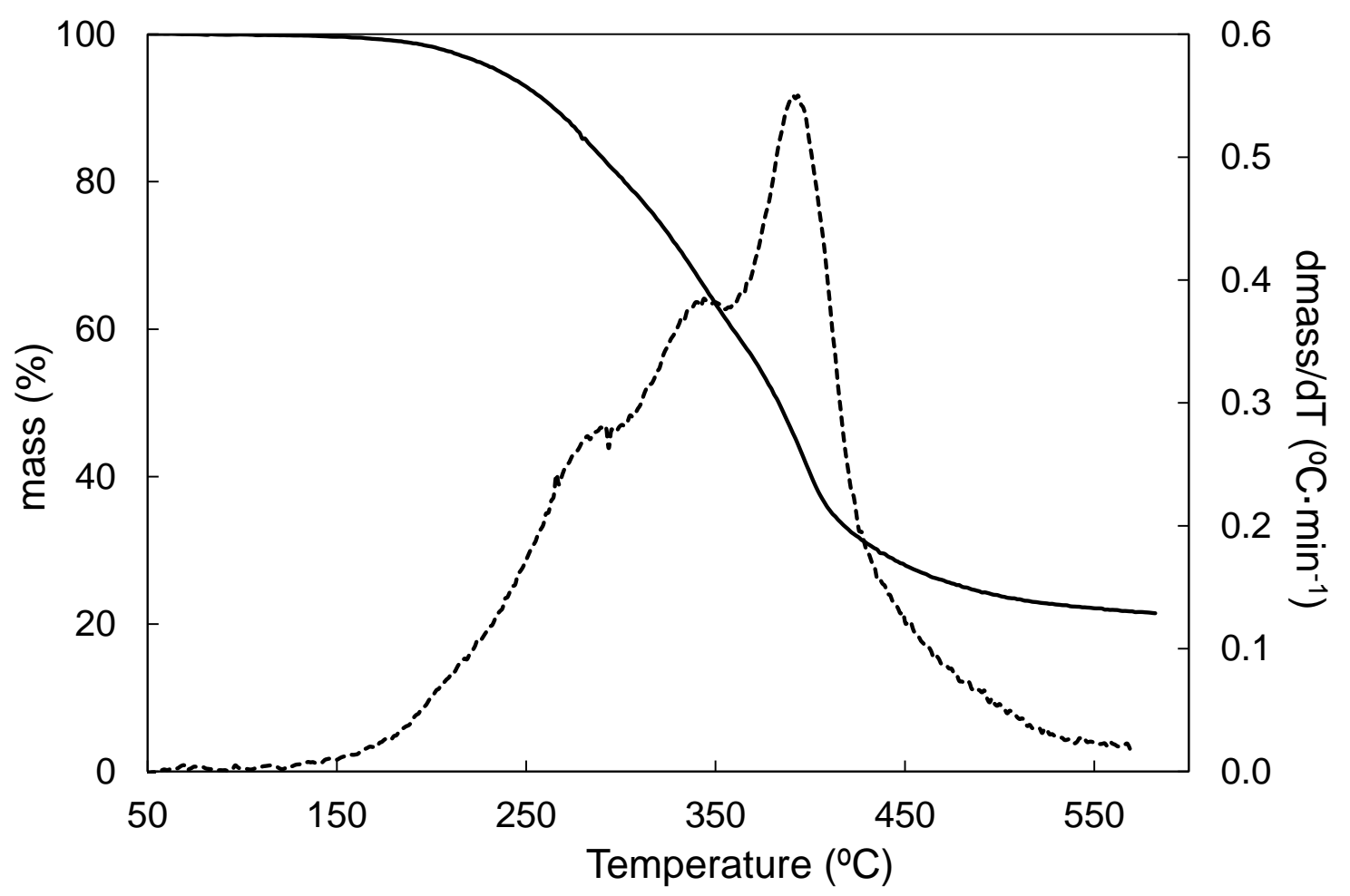

Figura 4. FTIR spectra of olive oil, raw TPOMW and t-TPOMW.

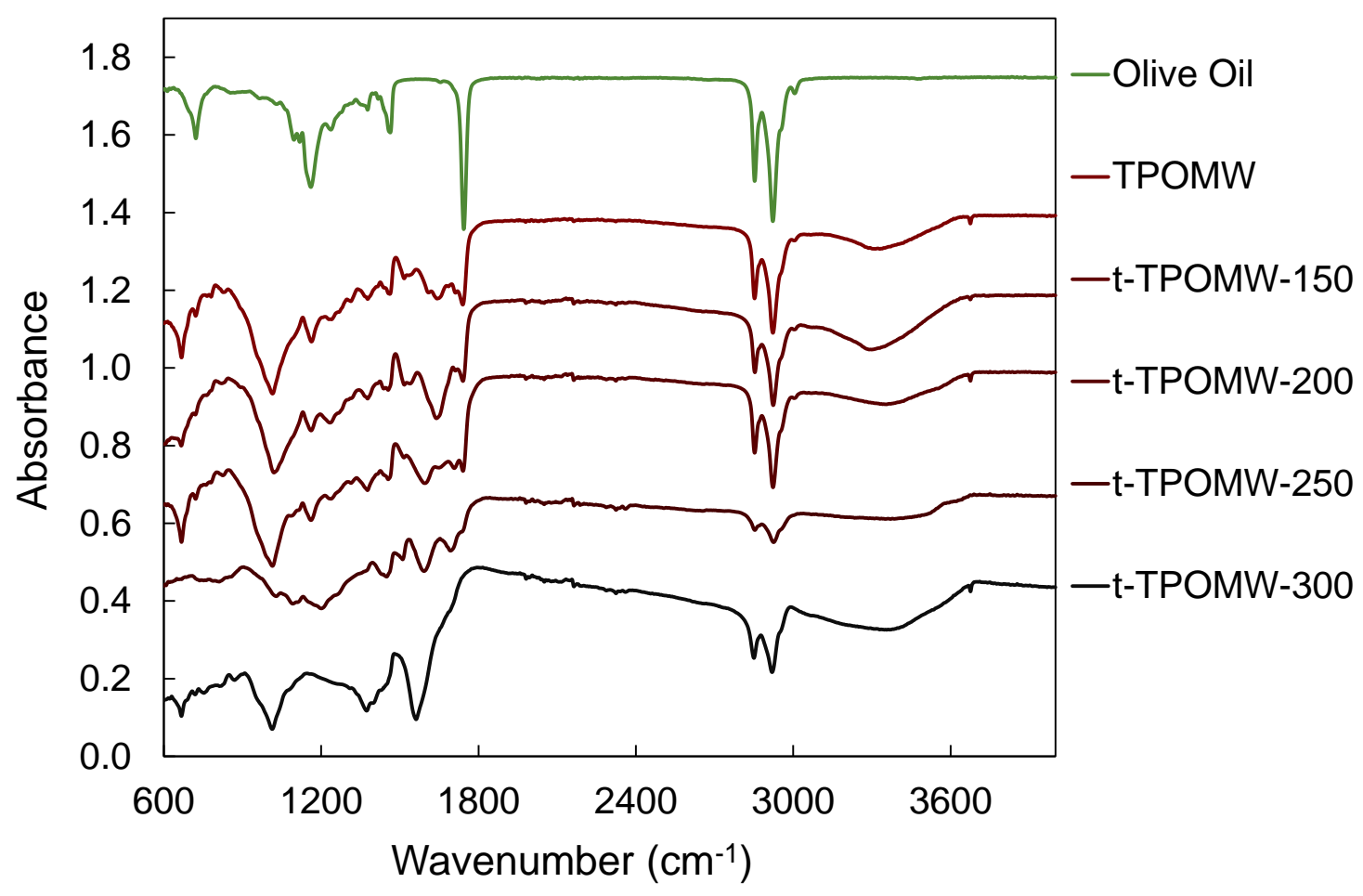


Figure 5. Energy recovery (\%) and solid yield (\%) for t-TPOMW.

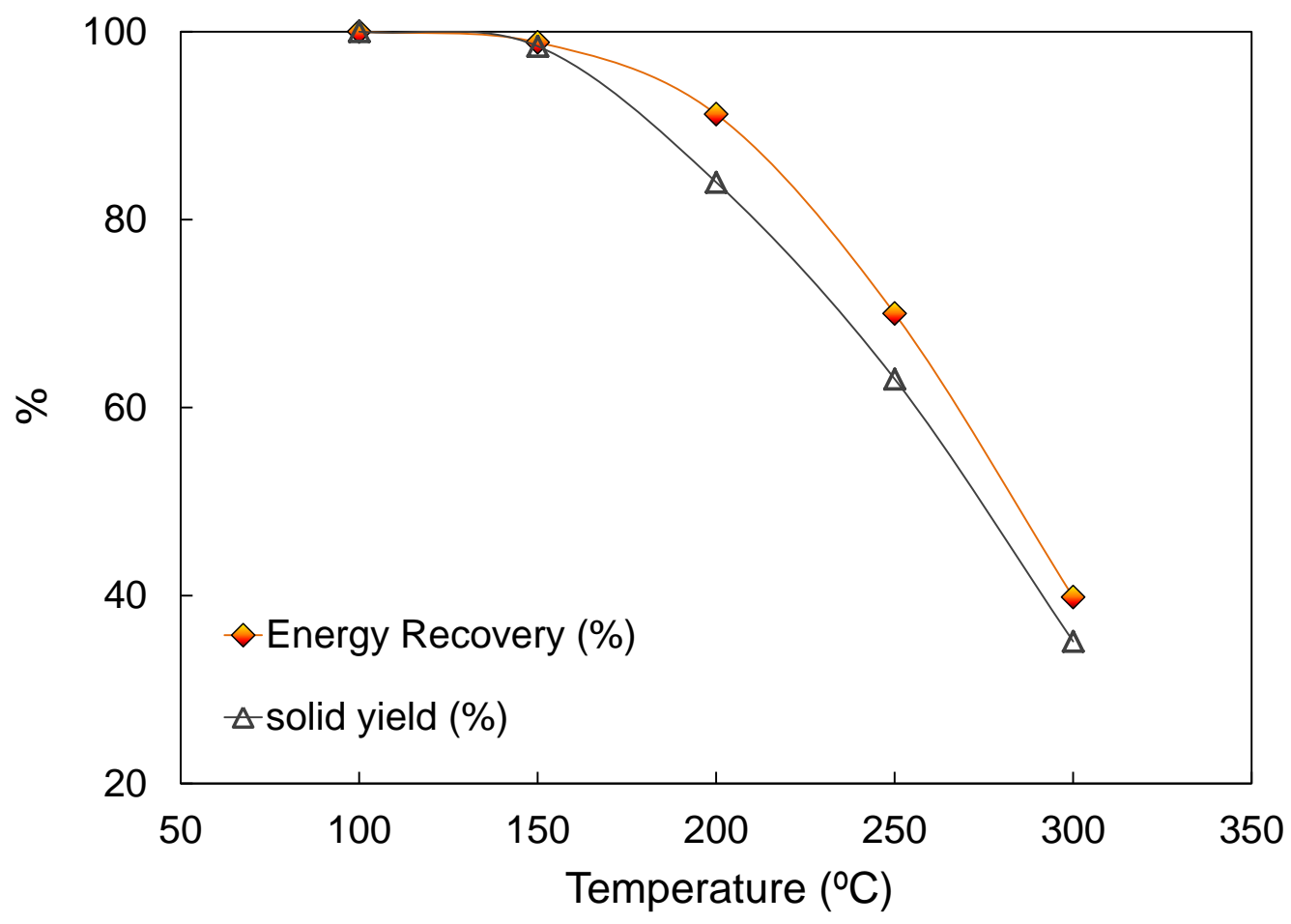

694

696 Figura 6. Calculated Torrefaction Energy Index (TEI) as a function of temperature for TPOMW and other agricultural wastes from the literature [7].

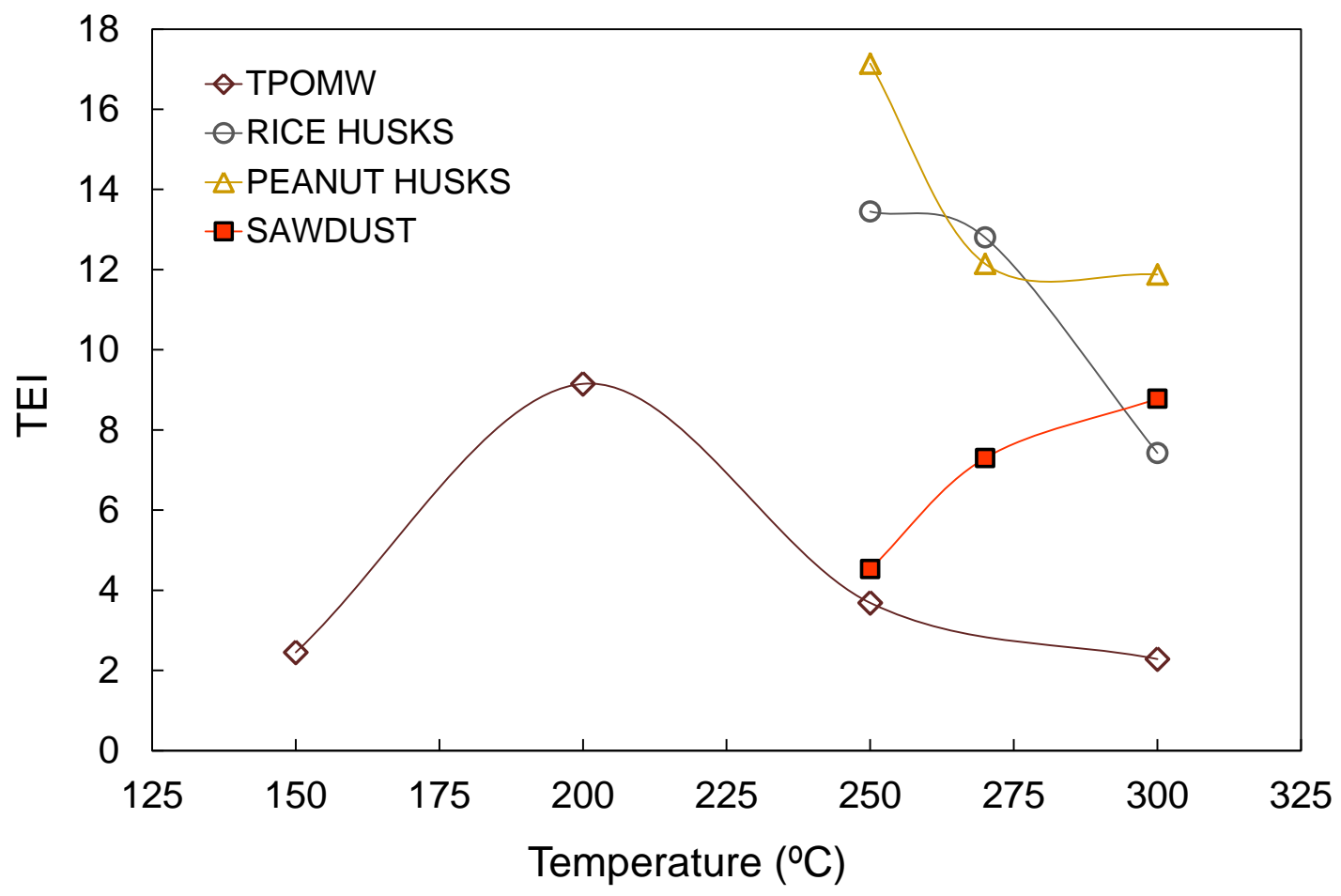

